\title{
Prevalence and associated factors of HIV infection among pregnant women attending antenatal care at the Yaoundé central hospital
}

\author{
Jeanne Hortence Fouedjio ${ }^{1 *}$, Florent Ymele Fouelifack ${ }^{1}$, \\ Loic Dongmo Fouelifa ${ }^{2}$, Robinson Enow Mbu ${ }^{1}$
}

\begin{abstract}
${ }^{1}$ Department of Obstetrics and Gynecology, Faculty of Medicine and Biomedical Sciences of the University of Yaoundé, Cameroon

${ }^{2}$ Faculty of Health Sciences, University of Lomé, Togo, School of Armies Health Services of Lomé, Togo

Received: 05 May 2017

Accepted: 29 May 2017

*Correspondence:

Dr. Jeanne Hortence Fouedjio,

E-mail: fouedjiojeanne@yahoo.fr

Copyright: ( ) the author(s), publisher and licensee Medip Academy. This is an open-access article distributed under the terms of the Creative Commons Attribution Non-Commercial License, which permits unrestricted non-commercial use, distribution, and reproduction in any medium, provided the original work is properly cited.
\end{abstract}

\begin{abstract}
Background: HIV infection affects millions of people worldwide, especially in sub-Saharan Africa. Transmission occurs by several means including the transmission from mother to child. The objective of this study was to determine the prevalence and factors associated with HIV infection in women attending antenatal care at the Yaoundé Central Hospital.

Methods: We conducted an analytical cross-sectional study at the Obstetrics and Gynecologic Unit of the Yaoundé Central Hospital from 6th October 2015 to 30th June 2016. The sampling was consecutive. We included 360 pregnant women. Testing was done by a sensitive test and a specific test if the first was positive. Data analysis was done through Excel 2007 software EpiData Analysis Version 3.2 and STATA version 12.0 (Texas USA 2001). Statistical significance was accepted for a value of $\mathrm{P}<0.05$.

Results: The average age of our population was $27.99 \pm 5.63$ years, ranging from 15 and 47 years. HIV prevalence in this population was $13.1 \%$ (47/360). Factors associated with HIV were the primary level of study $(\mathrm{OR}=7.97 ; 95 \%$ $\mathrm{CI}=2.23$ to $28.49, \mathrm{P}=0.001)$ and multiple sexual partners $(\mathrm{OR}=4.82$; $\mathrm{CI} 95 \%=2.24$ to $10.38, \mathrm{P}=0.002)$.

Conclusions: HIV prevalence in pregnant women at the Maternity of HCY is $13.1 \%$. The low level of education and multiple sexual partners were significantly associated with HIV infection. We suggest the education of the girls who is a key factor in the empowerment of women.
\end{abstract}

Keywords: Antenatal care, HIV, Prevalence, Pregnancy, Yaoundé

\section{INTRODUCTION}

In 2013, an estimated 35 million people were living with HIV (Human Immune Deficiency Virus) worldwide, nearly three quarter of them in sub-Saharan Africa. ${ }^{1}$ The prevalence of this infection varies from one continent to another and from one region to another within the same country. According to the latest demographic survey in 2011, the prevalence of HIV and AIDS (Acquired
Immune deficiency syndrome) was $4.3 \%$ in the general population in Cameroon. ${ }^{2}$

In the population of pregnant women, the average prevalence of HIV in 10 sentinel sites in Cameroon was $7.8 \%$ in 2013. The risk of HIV transmission from mother to child is $30-45 \%$ in the absence of any intervention. The Prenatal care is often the only contact opportunity with a health facility, for screening this infection. The Knowledge of status of pregnant women could reduce the 
risk of vertical transmission of HIV through the interventions of Prevention of mother to child. ${ }^{3}$

Our objective was to determine the prevalence and factors associated with HIV infection among pregnant women attending antenatal care (ANC) at the Yaoundé Central Hospital (YCH), and to identify factors associated with HIV infection in this population.

\section{METHODS}

We conducted an analytic cross-sectional study in the Obstetrics and Gynecology Unit of the Yaoundé Central Hospital over a period of 9 months, from $06^{\text {th }}$ October 2015 to $30^{\text {th }}$ June 2016 . The study population consisted of pregnant women attending ANC at the HCY. Were included all pregnant woman who gave the consent to participate in the study. Sampling was consecutive and comprehensive. During our study period, we offered each woman who came for ANC to participate in the study by explaining the objectives of the study. After obtaining consent, an examination was done to each of them to fill the preset specifications seeking:

- Socio-demographic data: age, marital status, occupation, education, religion, region of origin, place of residence

- Obstetric data: pregnancy, parity, gestational age.

- The history: blood transfusions, dental, surgery, HIV into the family

- The risk behaviors: tattoos, piercings, multiple partners, intravenous drug use.

After a well conducted counseling a levy was made for serological analysis and serology results were also recorded on the data sheet.

Each study participant was included in a special register; a unique identification number was assigned to each. $3 \mathrm{ml}$ of venous blood were taken aseptically using a $5 \mathrm{ml}$ syringe at the elbow crease then put in a dry tube previously identified. The samples were subsequently placed in tubes doors and left in ambient air for several hours to obtain serum.

We used strips (Alere Determine ${ }^{\mathrm{TM}} \mathrm{HIV}-1 / 2$ ) for rapid diagnosis: the search for the HIV antibody; this test has a sensitivity of $100 \%$ and a specificity for $99.89 \%$. This is a quick immunochromatographic test for visual reading for the qualitative detection of anti-HIV antibodies 1 and 2 . Serum deposited on the drop zone will migrate by capillary action taking with him the reagent already present on the membrane. Serum will meet the HIV antigen already present on the membrane to provide a visible color to the naked eye.

If the anti-HIV-1 and / or 2 are present, they will bind to the antigen of the conjugate selenium colloid-antigen and the antigen of the patient window by forming a red line.
If HIV antibodies are absent, the conjugate through the patient window without forming a red line.

\section{Interpretation}

- The test is positive when said two red bars appear in the patient and control zones of the strip,

- It is negative when no bar does not appear on the patient area of the strip but is present in the control area,

- The test is invalid if no red bar will appear on the 2 zones or if the bar appears only on the patient's area (Figure 1).

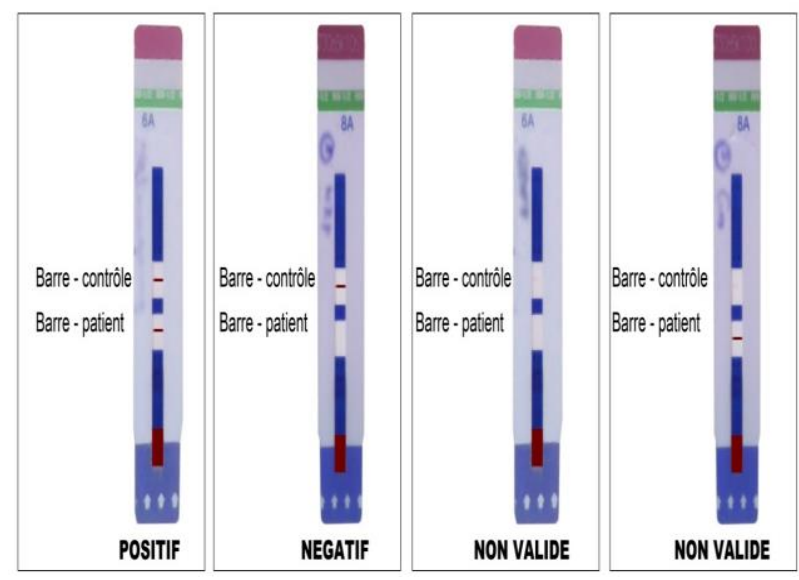

Figure 1: Possible results of the test by Alere determine TM HIV-1/2.

For those reactive to HIV determines a second test was done using another TDR OraQuick (OraQuick ADVANCE ® Rapid HIV -1/2 Antibody Test).

The results were given to each participant after post-test counselling. A review report was presented for confirmation to the Centre Pasteur of Cameroon. The results of the tests made at Centre Pasteur of Cameroon were all consistent with ours. These reactive HIV were transferred to the hospital the day of HCY for Antiretroviral therapy for life. The non-reactive women were advised to do a control test after 3 months.

The data collected were compiled on pre-established forms. They were subsequently returned to a database built with Epidata Entry version 3.1software. Microsoft Excel 2007 software, Epidata analysis Version 3.2 and STATA version 12.0 Transfer were used for data analysis. The descriptive analysis was used to calculate the frequencies, means, medians and standard deviation. The statistical test of chi- 2 and the Fisher's exact test were used to compare the frequencies with a threshold of significance $\alpha=5 \%$. The $\alpha$ error threshold was set at 5\% as statistically significant for each variable studied. The association between risk factors and each infection was done with the report of coastline (or odds ratio) expressed with its $95 \%$ confidence interval. The study of the association was made by univariate analysis at first, then 
logistic regression to eliminate confounding factors. Present project protocol was previously submitted to the Ethics Committee of the University of Douala / Faculty of Medicine and Pharmaceutical Sciences for obtaining ethical clearance allowing us to conduct our study that was made in strict compliance with ethics. We also received the authorization of research from the administration of Yaounde Central Hospital Women were clearly informed of the object of present study and their consent was obtained before inclusion in this study. The collected data served only for the study and the anonymity was preserved.

\section{RESULTS}

During the study period 1125 women came to ANC. We deleted 225 duplicates and 540 patients who did not give their consent to participate in the study. We finally analyzed a total 360 women.

\section{Serologic prevalence of $\mathrm{HIV}$}

From 360 women, 47 had positive serology of HIV, given the prevalence of $13.1 \%$.

\section{Risk factors associated with HIV}

Distribution of HIV seroprevalence according to sociodemographic characteristics.

Statistically significant differences between the 2 groups were observed in the age group of 30-34ans, levels of primary and secondary education and the student (Table $1)$.

Table 1: Distribution of HIV prevalence by socio-demographic characteristics.

\begin{tabular}{|c|c|c|c|c|c|}
\hline \multirow{2}{*}{ Variables } & \multirow{2}{*}{$\begin{array}{l}\text { Number } \\
\mathbf{N}=360\end{array}$} & \multicolumn{2}{|l|}{ HIV } & \multirow[t]{2}{*}{ OR (IC95\%) } & \multirow[t]{2}{*}{ P-value } \\
\hline & & $\begin{array}{l}\text { Positive }(\%) \\
47(13.1)\end{array}$ & $\begin{array}{l}\text { Negative (\%) } \\
313(86.9)\end{array}$ & & \\
\hline \multicolumn{6}{|l|}{ Age (years) } \\
\hline $15-19$ & 12 & 0 & $12(100)$ & NA & \multirow{4}{*}{0.06} \\
\hline $20-24$ & 96 & $5(5.2)$ & $91(94.8)$ & $1.93(0.84-3.04)$ & \\
\hline $25-29$ & 119 & $12(10.1)$ & $107(89.9)$ & & \\
\hline $30-34$ & 82 & $22(26.8)$ & $60(73.2)$ & $4,18(4.7-6.21)$ & \\
\hline $35-39$ & 41 & $6(14.6)$ & $35(85.4)$ & $2.14(0.79-5.78)$ & \multirow[t]{2}{*}{$<0.001$} \\
\hline $40+$ & 10 & $2(20.0)$ & $8(80.0)$ & $1.47(0.29-7.45)$ & \\
\hline \multicolumn{5}{|l|}{ Marital Status } & \multirow[t]{2}{*}{0.171} \\
\hline Married & 246 & $35(14.2)$ & $211(85,8)$ & $1,41(0,70-2,83)$ & \\
\hline Single & 114 & $12(10.5)$ & $102(89,5)$ & & \multirow{4}{*}{$\begin{array}{l}1.000 \\
0,401 \\
0,0007 \\
<0,01\end{array}$} \\
\hline \multicolumn{5}{|l|}{ Level of education } & \\
\hline Primaire & 30 & $14(46.7)$ & $16(55,3)$ & $3,60(1,57-8,24$ & \\
\hline Secondaire & 163 & $25(15.3)$ & $138(84,7)$ & $4,83(2,10-11,12)$ & \\
\hline Universitaire & 167 & $8(4.8)$ & $159(95,2)$ & & \\
\hline \multicolumn{6}{|l|}{ Profession } \\
\hline Remunerated activity & 148 & $21(14.2)$ & $127(85,8)$ & & \\
\hline Student & 145 & $6(4.1)$ & $139(95,9)$ & $3,83(1,50-9,79)$ & $<0,01$ \\
\hline House wife & 67 & $20(29.9)$ & $47(70,1)$ & $1,1(0,19-1,78)$ & 0,6 \\
\hline \multicolumn{6}{|l|}{ Region of origin } \\
\hline West & 145 & $12(8.3)$ & $133(91,7)$ & & \\
\hline Centre & 139 & $26(18.7)$ & $113(81,3)$ & $0,92(0,27-3,12)$ & 0,58 \\
\hline Littoral & 34 & $4(11.8)$ & $30(88,2)$ & $1,73(0,56-5,33)$ & 0,451 \\
\hline South-West & 14 & $1(7.1)$ & $13(92,9)$ & $2,99(0,37-23,90)$ & 0,466 \\
\hline Nord & 13 & $1(7.7)$ & $12(92,3)$ & $2,76(0,34-22,19)$ & 0,465 \\
\hline Est & 11 & $3(27.3)$ & $8(72,7)$ & $1,02(0,33-3,16)$ & 0,96 \\
\hline Others & 4 & 0 & $4(100)$ & - & \\
\hline \multicolumn{6}{|l|}{ Residency } \\
\hline Urban & 351 & $45(12.8)$ & $306(87.2)$ & $0,9(0,10-2,56)$ & 0,33 \\
\hline Rural & 9 & $2(22.2)$ & $7(77.8)$ & & \\
\hline \multicolumn{6}{|l|}{ Religion } \\
\hline Christian & 336 & $45(13.4)$ & $291(86.6)$ & & \\
\hline Muslim & 21 & $1(4.8)$ & $20(95.2)$ & $3,09(0,41-23,61)$ & 0,496 \\
\hline Other & 3 & $1(33.3)$ & $2(66.7)$ & $0,31(0,03-3,48)$ & 0,355 \\
\hline
\end{tabular}


Distribution of HIV seroprevalence based on obstetric characteristics: There is a statistically significant difference in the 2 groups for primigravida and pauciparous (Table 2). Association between risk behaviors and HIV. There is a statistically significant difference in 2 groups for tattoo and multiple sexual partners (Table 3).

Table 2: Distribution of HIV prevalence based on obstetric characteristics.

\begin{tabular}{|llllll|}
\hline Variables & $\begin{array}{l}\text { Number } \\
\text { N=360 }\end{array}$ & $\begin{array}{l}\text { VIH } \\
\text { Positive (\%) } \\
\mathbf{4 7}(\mathbf{1 3 , 1 \%})\end{array}$ & $\begin{array}{l}\text { Negative (\%) } \\
\mathbf{3 1 3}(\mathbf{8 6 , 9 \%})\end{array}$ & OR (IC95\%) & P-value \\
\hline Gravidity & & & & \\
\hline Primigravida & 91 & $1(1,1)$ & $90(98,9)$ & $0,84(0,79-0,89)$ & $<0,0001$ \\
\hline Multigravida & 269 & $46(17,1)$ & $223(82,9)$ & & \\
\hline Parity & & & & \\
\hline Nulliparous & 117 & $5(4,3)$ & $112(95,7)$ & & 0,136 \\
\hline Primiparous & 94 & $12(12,8)$ & $82(87,2)$ & $0,54(0,25-1,16)$ & 0,002 \\
\hline Pauciparous & 108 & $23(21,3)$ & $85(78,7)$ & $3,1(2,5-3,61)$ & 1,000 \\
\hline Multiparous & 25 & $5(20)$ & $20(80)$ & $1,08(0,37-3,20)$ & \\
\hline Grand multiparous & 16 & $2(12,5)$ & $14(87,5)$ & $1,89(0,4-8,94)$ & 0,523 \\
\hline Gestational age & & & & \\
\hline $1^{\text {st }}$ trimester & 84 & $12(14,3)$ & $72(85,7)$ & $1,18(0,54-2,58)$ & 0,688 \\
\hline $2^{\text {nd }}$ trimester & 131 & $17(13,0)$ & $114(87,0)$ & $1,1(0,23-2,54)$ & 0,48 \\
\hline $3^{\text {th }}$ trimester & 145 & $18(12,4)$ & $127(87,6)$ & $1,05(0,52-2,14)$ & 1,000 \\
\hline
\end{tabular}

Table 3: Risk behaviour and HIV infection among participants.

\begin{tabular}{|c|c|c|c|c|c|}
\hline Variables & $\mathrm{N}=360$ & $\mathrm{HIV}+\mathrm{n}=47$ & HIV-n= 313 & OR (IC95\%) & P-value \\
\hline \multicolumn{6}{|c|}{ Blood transfusion } \\
\hline Yes & 25 & $3(12,0 \%)$ & $22(88,0 \%)$ & $0,90(0,26-3,14)$ & 1,000 \\
\hline No & 335 & $44(13,1 \%)$ & $291(86,9 \%)$ & & \\
\hline \multicolumn{6}{|l|}{ Tattoo } \\
\hline Yes & 31 & $9(29,0 \%)$ & $22(71,0 \%)$ & $3,13(1,34-7,30)$ & 0,017 \\
\hline No & 329 & $38(11,6 \%)$ & $291(88,4 \%)$ & & \\
\hline \multicolumn{6}{|l|}{ Scarification } \\
\hline Yes & 107 & $18(16,8 \%)$ & $89(83,2 \%)$ & $1,56(0,83-2,95)$ & 0,174 \\
\hline No & 253 & $29(11,5 \%)$ & $224(88,5 \%)$ & & \\
\hline \multicolumn{6}{|l|}{ Piercing } \\
\hline Yes & 9 & $2(22,2 \%)$ & $7(77,8 \%)$ & $1,94(0,39-9,65)$ & 0,332 \\
\hline No & 351 & $45(12,8 \%)$ & $306(87,2 \%)$ & & \\
\hline \multicolumn{6}{|c|}{ Multiple sexual Partners } \\
\hline Yes & 36 & $13(36,1 \%)$ & $23(63,9 \%)$ & $4,82(2,24-10,38)$ & 0,0002 \\
\hline No & 324 & $34(10,5 \%)$ & $290(89,5 \%)$ & & \\
\hline \multicolumn{6}{|l|}{ Dental care } \\
\hline Yes & 94 & $8(8,5 \%)$ & $86(91,5 \%)$ & $0,54(0,24-1,21)$ & 0,155 \\
\hline No & 266 & $39(14,7 \%)$ & $227(85,3 \%)$ & & \\
\hline \multicolumn{6}{|c|}{ Recent surgery } \\
\hline Yes & 47 & $5(10,6 \%)$ & $42(89,4 \%)$ & $0,77(0,29-2,05)$ & 0,816 \\
\hline No & 313 & $42(13,4 \%)$ & $271(86,6 \%)$ & & \\
\hline \multicolumn{6}{|c|}{ Family history of HIV } \\
\hline Oui & 34 & $13(38,2 \%)$ & $21(61,8 \%)$ & & \\
\hline Non & 203 & $20(9,9 \%)$ & $183(90,1 \%)$ & NA & 0,0001 \\
\hline Non précisé & 123 & $14(11,4 \%)$ & $109(88,6 \%)$ & & \\
\hline
\end{tabular}




\section{Logistics regression}

After logistic regression, the level of primary instruction and multiple sexual partners are factors associated with HIV infection in pregnant women (Table 4).

Table 4: Logistic regression of HIV correlate factors.

\begin{tabular}{|lccl|}
\hline Variables & OR & IC95\% & P-value \\
\hline Primary level & 7,97 & $2,23-28,49$ & 0,001 \\
\hline $\begin{array}{l}\text { Multiple sexual } \\
\text { partners }\end{array}$ & 4,79 & $1,79-12,79$ & 0,002 \\
\hline
\end{tabular}

\section{DISCUSSION}

\section{Prevalence of HIV infection}

The prevalence of HIV infection in pregnant women was $13.1 \%$ in the maternity of the Yaoundé Central Hospital. This result was far superior to that found by Billong et al in $2012(7.8 \%)$ during their study in 10 sentinel sites in Cameroon, also some studies in some African countries including the Democratic Republic of Congo 2013 $(4.3 \%)$ and $(6.6 \%)$ in 2014 in Ethiopia. ${ }^{4-6}$

The superiority of our results compares to Billong and al can be explained by the fact that we recruited not only pregnant women attending health facility while Billong et al did a community based study. ${ }^{4}$

This high prevalence can also be explained by the fact that the maternity of $\mathrm{YCH}$ is a reference centre in the Yaounde town for the prevention of mother to child transmission where we can found well trained staff.

Our result is similar to the foundings of Fouedjo et al who reported in 2012, a prevalence of $11.26 \%$ among women who delivered in $\mathrm{YCH}^{7}{ }^{\text {This }}$ result is closed to that of Kasenga et al that in 2009 in a rural area of Malawi found themselves an HIV prevalence of $15.6 \%$ in pregnant women. ${ }^{8}$

\section{Factors associated with HIV}

Concerning age, the age group of 25-34 years was significantly associated with HIV. Okerentugba et al in 2015 in Nigeria had found that age is associated with HIV in pregnant women. ${ }^{9}$ This same age group 25-34 years was also found to be associated with HIV in a study in 2011 in Tanzania. ${ }^{10}$

The high prevalence of HIV in this age there can be explained by the fact that at this age women are sexually very active and therefore very vulnerable to HIV.

According to the education level, the primary level was statistically associated with HIV even after multivariate analysis. Billong et al also found a high prevalence of HIV in this group during their sentinel study in Cameroon in 2012. ${ }^{4}$ This result is similar to the latest
EDS-MICS 2011 of Cameroon who found a higher prevalence HIV among women with a primary level of study. ${ }^{2}$ Another sentinel study in Haiti in 2007 found the same result. ${ }^{11}$

This could be explained by the fact the level of education is correlated to the understanding the health education messages issues on advantages of good behaviors and behavior changes. Concerning occupation, HIV-infected women in this study were mostly housewives. Billong et al found in their study that women with low incomes were most affected with HIV. ${ }^{4}$ In 2008 , a study in Mali reported the same result. ${ }^{12}$

According to obstetric characteristics, pauciparity was significantly associated with HIV. While the primigravida and nulliparity were protective factors.

We could not find any information in the literature on the influence of gender and pregnancy on the incidence of HIV. Nevertheless, we can explain this result by the fact that high parity stems from multigravida and being multigravida proves a multiplicity of unprotected sex that increase the risk of becoming infected with HIV. The analysis of risk behavior demonstrated that multiple sexual partners and tattoos were associated with HIV. Bankole also found that these factors are associated with HIV in Nigeria in 2012. ${ }^{13}$

Limitations of this study was conducted in health facility, the Maternity; therefore, the results cannot be generalized because the arised from hospital based data.

\section{ACKNOWLEDGMENTS}

Authors would like to thank Yaoundé Central Hospital who gave us permission to carry out the study at their institution.

\section{Funding: No funding sources \\ Conflict of interest: None declared \\ Ethical approval: The study was approved by the Institutional Ethics Committee}

\section{REFERENCES}

1. UNAIDS. The gap report; 2014. available from http://www.unaids.org/en/ressources/documents/201 4/20140716 unaids gap report.

2. Demographic and Health Survey of Cameroon (EDSMICS). HIV prevalence in Cameroon: results; 2011.

3. Ngemu E, Khayeka C, Kweka E, Choge J, Anino E, Oyoo E. Effectiveness of option B highly active antiretroviral therapy (HAART) prevention of mother-to-child transmission (PMTCT) in pregnant HIV women. BMC Res Notes. 2014;7:52.

4. Billong S, Fokam J, Billong E, Tsague G, MarieJosée E, Fodjo R, et al.

5. Epidemiological distribution of HIV infection among pregnant women in the ten regions of Cameroon and 
strategic implications for prevention programs. Pan Afr Med J. 2015;23:3-9.

6. Kabinda JM, Akilimali TS, Miyanga AS, Donnen P, Michèle D-W. Hepatitis B, Hepatitis C and HIV in pregnant women in the community in the Democratic Republic of Congo. World J AIDS. 2015;5(02):124.

7. Zenebe Y, Mulu W, Yimer M. and Abera B. Seroprevalence and risk factors of hepatitis $b$ virus and human immunodeficiency virus infection among pregnant women in Bahir Dar city, Northwest Ethiopia: a cross sectional study. BMC Infect Dis. 2014;14:118.

8. Fouedjio J, Mbu R E, Fouelifack Y F, Kamga T, Wandji Nana J. Caesarean section in HIV-Infected Women: Materno-Fetal Prognosis at the Maternity Hospital of Yaounde Central Hospital. Health Sci Dis. 2014;15(3):1-7.

9. Kasenga F, Byass P, Emmelin M, and Hurtig AK. The implications of policy changes on the uptake of a PMTCT programme in rural Malawi: first three years of experience. Glob Healt Act. 2009;2:1-7.

10. Okerentugba PO, Uchendu SC, Okonko IO. Prevalence of HIV among pregnant women in Rumubiakani, Port Harcourt, Nigeria. Pub Health Res. 2015;5(2):58-65.

11. Manyahi J, Boniphace S, Jullu, Mathias I, Abuya, Juma J. Prevalence of HIV and syphilis infections among pregnant women attending antenatal clinics in Tanzania. BMC Public Health. 2015;15:501.

12. Ministry of Public Health and Population, Haitian Institute of Childhood. Sentinel serosurveillance study on the prevalence of HIV, Syphilis, hepatitis B and hepatitis $\mathrm{C}$ among pregnant women in Haiti 2006/2007, GHESKIO Centers; Centers for Disease Control and Prevention, Port-au-Prince, Haiti, July; 2007.

13. Adama G. Prevalence of HIV infection among pregnant women at the Fousseynidaou hospital in Kayes [Thesis]. Medicine: Kayes; 2008:55.

14. Bankole HO, Omoregie R, Oladeinde BO. Prevalence of HIV, HBV and HCV infections among pregnant women receiving antenatal care in traditional birth home in Benin city, Nigeria. Saudi J Health Sci. 2013;2(2):113-7.

Cite this article as: Fouedjio JH, Fouelifack FY, Fouelifa LD, Mbu RE. Prevalence and associated factors of HIV infection among pregnant women attending antenatal care at the Yaoundé central hospital. Int J Reprod Contracept Obstet Gynecol 2017;6:2698-2703. 